\title{
ROTI GAMBANG, ACCULTURATION BREAD FROM BETAWI
}

\author{
Nurul Sukma Lestari \\ Hotel Management Department \\ Universitas Bina Nusantara \\ nurul.lestari@binus.edu
}

Submitted : 28 February 2020 Revised:27 March 2020

Accepted :30 March 2020

\begin{abstract}
ABSTRAK
Tujuan dari penelitian ini adalah untuk mengetahui sejarah dari Roti Gambang, keunikan dan cara melestarikan keberadaan roti ini. Pemilihan roti gambang disebabkan karena roti ini adalah makanan traditional khas Betawi. Metode yang digunakan adalah metode kualitatif dengan pendekatan studi literatur. Hasil yang diperoleh dari penelitian ini adalah Roti Gambang berasal dari era kolonial. Keunikan roti ini adalah bentuknya yang persegi yang mengadopsi bentuk salah satu alat musik dari Gambang Kromong, yaitu Gambang serta penggunaan kayu manis dan gula merah. Roti ini mencapai popularitasnya pada akhir 1980-an dan 1990-an. Roti Gambang sudah mulai dijual di toko makanan yang ada di jaringan bioskop terbesar di Indonesia dan sudah tersedia juga di salah satu gerai Starbuck Comunnity Store di Jakarta. Disarankan untuk menjaga keberadaan Roti Gambang karena roti tersebut memiliki nilai sejarah dan terpilih menjadi salah satu roti paling enak di dunia berdasarkan CNN.
\end{abstract}

Kata Kunci : Betawi, Nilai Sejarah, Roti Gambang

\section{ABSTRACT}

The purpose of this research is to find out the history of Roti Gambang, the uniqueness and how to preserve the existence of this bread. Roti Gambang has been chosen because it's a traditional bread from Betawi. A qualitative method with a literature study approach used in this research. The results from this research are the bread originating from the colonial era. The uniqueness is a square shape that adopts the shape of Gambang, the musical instruments from Gambang Kromong and the use of cinnamon and brown sugar. Reached the popularity in the late 1980s and 1990s. The Bread is available at food stores in the largest cinema chain in Indonesia at one of the Starbuck Community Store outlets in Jakarta. It's recommended to maintain the existence of the Roti Gambang because of historical value and it was chosen to be one of the most delicious bread in the world based on CNN.

Keywords: Betawi, Historical Value, Roti Gambang

\section{INTRODUCTION}

The travel and tourism sector globally up to 2018 grew by $3.9 \%$, and provided 319 million job vacancies, equivalent to $10 \%$ of total workers worldwide and contributed \$
8.8 trillion to the world economy (Manzo \& Smith, 2019). In the National Medium-Term Development Plan (RPJMN) 2015 - 2019, the Indonesian government establishes tourism as a leading sector because in the 
short, medium and long-term growth is positive (Kementerian Pariwisata Indonesia, 2018). Tourism has several components, including the culinary field which can be one of the motivations for someone to visit certain tourist areas (Zahrulianingdyah, 2018). Food and beverage products contributed $19.33 \%$ of the total revenue in the field of Tourism in Indonesia (Tanico, Dafila, 2016). The latest trend that growing and increasing rapidly is the combination of food and tourism (Zainal, Zali, \& Kassim, 2010).

Food tourism in recent years has developed rapidly and has become one of the most dynamic and creative tourism segments, and has encouraged tourism diversification and stimulated the development of local, regional and national economies (World Tourism Organization, 2012). Food plays several important roles including as a tourist attraction, can increase tourist visits, provide experience for visitors, provide an identity for an area and play an active role in the sustainability of the competitiveness of tourist destination (Steinmetz, 2010). So it can be concluded that the relationship between tourism and food is very close because food can be a differentiator or characteristic of a tourist destination with one another (Maurer, 2019). Indonesia is a vast country and consists of various ethnicities, which has a culture and special food that can be used as an attraction for tourists to visit an area (Gultom, 2015).

Local food can be used as an attraction for tourists because local food has an identity, become the pride of an area and can contribute to the development of Tourism (Mnguni \& Giampiccoli, 2019). As seen in previous studies (Lestari \& Natalina, 2019) which state that many traditional foods and drinks are closely related to culture, or can be said to have been closely attached to an area.

What distinguishes culinary tourism with other tourism is that culinary tourism prioritizes food originating from a tourist destination which is judged in terms of the superiority of the food, both the taste and distinctiveness of the food regardless of the natural beauty or tourist trinkets in the area (Kurniawan, 2010). But the impact of local food on the tourist experience is often overlooked (Sengel, et al., 2015). Where traditional food can be an attraction from a place. As expressed by (Sert, 2019) that trying the local food at a destination becomes one of the most important tourism activities for tourists. Because the value of consumption from local food can explain the attitude of tourists towards local food, the image of the food destination, and the behavioral intentions of the tourists (Cho \& Kim, 2018). And Indonesian food is no less interesting than food from other countries and can be used as a tourist attraction (Anugrah, 2018).

One area that has local specialties is Jakarta or formerly known as Betawi. Betawi has a culinary diversity (Krisnadi, 2018), because Betawi is a result of the acculturation process of several tribes in Indonesia and several countries in the world (Untari, Darusman, Prihatno, \& Arief, 2018). Meanwhile, according to Harris in. (Erwantoro, 2014) Indians, Chinese, Muslims, and Europeans are countries that affect various aspects of life from ethnic Betawi (Jakarta).

Betawi has a variety of culinary specialties one of which is Roti Gambang that is almost non-existent (Tempat Wisata Indonesia, 2017). Roti Gambang is a legacy of the colonial era that has a unique and distinctive taste (Jakarta tourism, 2018). Roti Gambang is categorized as a snack or often referred to as a typical Betawi snack that has a sweet taste and sesame seeds (Indriani \& Frizona, 2018). Roti Gambang has a high historical value, due to a mixture of influences from the Dutch and traditional Indonesian spices. This combination produces bread that has a texture and a different taste from bread in general. Therefore recently the bread was included in the '50 most delicious bread from all over the world' released by CNN where this list was 
accredited by a former Pastry Chef named Jen Rose Smith (CNN Indonesia, 2019). his list was issued on October 16, which is World Bread Day (Mutiah, 2019).

Roti Gambang reached popularity in the late 1980s and 1990s (Aditya, 2019). Along with the globalization era, traditional Betawi food began to be abandoned (Astari, 2019).

The purpose of this research is to find out the history of Roti Gambang, the uniqueness and how to preserve the existence of this bread

\section{LITERATURE REVIEW Jakarta City}

The Special Capital Region of Jakarta, which we know as the Capital of the Republic of Indonesia, is located on the island of Java between Banten Province and West Java Province. It has an area of 664.01 $\mathrm{km} 2$ with a population density of $9,992,842$ inhabitants, and before becoming Jakarta has undergone several name changes (Primadia, 2016).

Sunda Kelapa is the first name, which later changed to Jayakarta on June 22, 1527, which was subsequently set as the date of the founding of the city of Jakarta (Jakarta Tourism, 2020). In 1619 the Dutch captured Jayakarta, which subsequently changed its name to Batavia (Ridwiyanto, 2011). And when Japan entered Indonesia in 1942, Batavia was changed to Djakarta Tokubetsu Shi ' (Utiket, 2020) In 1945 at the time of the proclamation of independence, the Japanese name was removed from being only Djakarta (Indonesia.go.id, 2018) And only in 1972 changed from the old spelling to the new spelling, Jakarta, which continues to be used until now (Utiket, 2020).

\section{Ethnic Betawi}

Ethnicity is a group of people who are classified based on beliefs and religion, racial equality, customs, language, history and are the same descendants of the same ancestors so that the social group can create a cultural system that binds the human group itself within it (Aljauhari, 2017). The Betawi ethnic group was formed from a process of assimilation between ethnic groups and became an ethnic origin from Jakarta which was echoed by the Dutch government for political interests in the past (Suswandari, 2017).

Betawi is an indigenous ethnic group in Jakarta where it was once known as Batavia (Untari, Avenzora, Darusman, Prihatno, \& Arief, 2016). But in general, the Betawi ethnic group is a mixture of various ethnic groups originating from the territory of Indonesia and even foreign nations such as Portuguese, Indian, Chinese, Arabic, Dutch, and so on (Erwantoro, 2014). As an ethnicity, the Betawi community certainly has its characteristics so that it can be distinguished from other ethnicities, the Betawi people are fanatics of Islam, they speak with a distinctive Malay dialect, and are known as an egalitarian society who can accept anyone regardless of race or his religion (Lukmansyah, Wasino, \& Ahmad, 2016).

Betawi culture such as art, architecture, customs, traditions, literature, folklore, food and culinary are become the potential tourist attractions (Sutisna, n.d.)

\section{Traditional Cuisine}

Culinary is the preparation, processing, and serving of dishes in the form of side dishes and drinks (Ketaren, 2017). The culinary term is derived from the English "culinary" which is defined as food or kitchen (Alamsyah, 2008). Food choices depend on various factors such as ethnicity, culture, religious beliefs, population status, and many more (Begum , 2009). Traditional food or local food is one of the identities of a group of people that is very easy to find and easy to recognize (Tyas, 2017). Local cuisine is an important part of gastronomy because it not only provides experience but connects everything that accompanies it such as culture, history, art, and health (Nariani, 2019).

According to Sastroamidjojo inside (Muliani, 2019) which can be categorized as traditional foods are foods that have the 
following criteria: (1) commonly consumed for several generations, (2) has a taste that matches the tastes of the community, (3) does not conflict with the religion, beliefs, and beliefs of the local community, (4) made from food ingredients and spices available around the local environment.

\section{Betawi Traditional Food}

The city of Jakarta is a place of mixing of various tribes and nationalities which produces spices and Betawi culinary profiles that exist today (Gardjito, Putri, \& Dewi, 2018). Betawi specialties, as well as its culture, are also a combination of elements from outside such as culinary from China, the Middle East and the Netherlands (Balqis, 2015).

Betawi Ethnic have many food choices that have the potential to be promoted as a tourist attraction (Muliani, 2019). Many tourists spend more time and money to taste unique foods and drinks, because through food can be found a new taste, texture, culture and heritage (Wolf, 2019)

\section{Gastronomy}

Gastronomy is a study that studies various components of culture with food as a center (Maligan, 2013). While according to Taqwani in (Sani, Alia, \& Riyadi, 2016) states that gastronomy is a study that studies the relationship between culture and food. Gastronomy has become one of the main sources of attraction for tourist destinations (Gálvez, López-Guzmán, Buiza, \& MedinaViruel, 2017).

The features of the gastronomy study consist of four components (Ketaren, 2017) that are: (1) Culture: local ethnic factors including religion, beliefs, customs and traditions and values of local wisdom, (2) History: the origin of the cultivation of raw materials for cooking and the ability to innovate in the components, textures, and flavors in food, (3) Geographical landscape: geographical \& climatic factors as well as the diversity level of local and ethnic migrants, (4) Cooking methods: cooking techniques and processes in general.
Gastronomy includes three aspects, namely culture, history and geographical landscape (Ketaren, 2017). Gastronomy is used in this research to examine roti Gambang from the process, the history, culture, and cooking techniques by finding the origin/history scientific writing, including innovation for new recipes or modifications to traditional recipes (Ketaren, 2017).

\section{METHOD}

Based on the formulation of the problem under study, the method used in this study is descriptive with a qualitative approach. This research is a literature study that is one of the qualitative methods. According to Strauss and Corbin in (Nugrahani , 2014) stated that qualitative research is research that can be used to examine people's lives, history, behavior, organizational functionalization, social movements, or kinship relations.

Research with literature studies do not have to have respondents, because the data needed in research can be obtained from library sources or documents (Melfianora, 2019).

Data obtained through qualitative research are more words or information (Junaid, 2016). So the data collection method used in this study is documentation. Where documentation is an activity involving documents, such as books, journals, newspapers, magazines, files, photos, videos or sound recordings (Soraya, 2017).

The documents in this study are data in the form of books, articles, journals, and files on the origin or history of roti gambang, their characteristics and how they can be repopularized. The books used in this study are the books that have information about traditional Indonesian cuisine, especially Betawi.

\section{RESULT AND DISCUSSIONS History of Roti Gambang}

Roti Gambang is a bread with a natural brown color obtained from the use of 
brown sugar as one of the basic ingredients (Netralnews.com, 2017). According to some sources, the origin of this bread has existed since the colonial era and some even say that this bread was introduced by the Dutch. Roti Gambang was consumed in the by Dutch Indonesians during the colonial period (Aditya, 2019). Roti Gambang has a twin originating from the Semarang, named roti 'Ganjel Rel' because according to the Javanese people at that time the shape resembled rail pads (Kompas.com, 2019).

Meanwhile, according to the Betawi people, the origin of this bread called gambang is because of its shape which is similar to the "gambang" one of the musical instrument of Gambang Kromong and based on the Betawi culturist Yahya Adi Saputra the Gambang Kromong has been known since the 18th century (Jendela Informasi Kuliner , 2019).

Gambang is a musical instrument which is one of the mandatory musical instruments in the art of Gambang Kromong orchestra, where this musical instrument is made from iron or brass rods arranged in a row to produce a harmonious sound when struck (Manoto, 2016). The Gambang Kromong itself is cultural acculturation, between Indonesian culture and Chinese culture (Harlandea, 2016).

Roti Gambang is considered to reflect the character of the citizens of Jakarta, which illustrates that Jakarta people are very fond of friends, like to live in groups and do not like solitude and love to talk and stay in a crowd (Rara, 2019).

The first maker of this bread is not yet known. But two bread factories have a history in making Roti Gambang, the first is the Roti Lauw factory which was established in 1960 and located at Kebon Kacang Gang 1, Central Jakarta, and the second is the Tan Ek Tjoan bread factory which started its business in the Surya Kencana area Bogor in 1921 and opened a branch in Jakarta in 1955 located at Jalan Cikini Raya, North Jakarta (Irvansetiawan, 2019).

\section{The uniqueness of Roti Gambang}

Roti Gambang is a legacy of the Dutch era that is increasingly difficult to find now. Roti Gambang is cultural acculturation in the form of a combination of breadmaking techniques brought by the Dutch and the use of local Indonesian ingredients, giving rise to the distinguishing characteristics of other products. According to (Irvansetiawan, 2019) special characteristics of Roti Gambang are: (a) gambang bread has a soft texture but not as soft as bread, (b) distinctive flavor with a dominant cinnamon powder fragrance, (c) a sweet taste that is not too strong due to the use of palm sugar and brownish color from the natural color of brown sugar and (d) There is a sprinkling of sesame on bread as a garnish.

But according to (Sari , 2015) what distinguishes roti gambang with others bread, in general, are: (a) ordinary bread uses a yeast, while roti gambang uses baking powder as a leavening agent, (b) the use of brown sugar as a substitute for white sugar, and the last is (c) cinnamon-scented sweet, where ordinary bread generally uses spekoek/lapis legit

\section{A way to preserve the existence of Roti Gambang}

The city of Jakarta, which continues to grow and become modern, has an impact on the increasingly disappearing Betawi ethnic (Yustiana \& Halim, 2019) so that it also impacts on the existence of Roti Gambang. Several ways have been done so that the Bread Gambang is not lost in time. (1) To re-popularize Roti Gambang is by working with a large cinema network in Indonesia, the goal is that young people can get to know and taste bread that has high historical value (Setyorini, 2019), (2) One of the famous coffee shops, Starbuck Community Store, located in Tanah Abang, Central Jakarta, serves Betawi drinks and snacks, one of which is Roti Gambang. Where this is done by Starbucks outlets to attract interest from the community (Sopia, 2020). 


\section{CONCLUSION}

It can be concluded based on the results obtained from the supporting materials available that the Roti Gambang is a relic of the Dutch colonial era and is an acculturation of bread-making techniques brought by the Dutch people with distinctive Indonesian flavors. It is a traditional food from the Betawi people which is included in the snack food category.

It has a characteristic form of texture that is hard on the outside and soft on the inside, has a unique aroma and taste obtained from the use of cinnamon, natural brown color due to the use of brown sugar and the presence of sesame sprinkles on the top.

Some of the efforts made so that Roti Gambang still exists today is by selling in food stores in the largest cinema network in Indonesia and the availability of Roti Gambang as one of the Betawi special snacks in one of the famous coffee shops, namely Starbuck Community Store.

Tourism development is inseparable from the role of the local community, support and community participation is needed (Edison, Kartika, \& Dewi, 2019).

The advice that researcher can give is that cultural festivals are held where traditional food is re-introduced, making interesting packaging along with its history so that tourists at the time of buying can know a little about its history. Selling roti gambang in shops that sell special souvenirs from Jakarta.

\section{REFERENCES}

Aditya, N. (2019, Oktober 21). Kisah Tentang Roti Gambang, Kenangan Menyantap Roti Terbaik Dunia. Retrieved from Kompas.com: https://ravel.kompas.com/read/2019/ 10/21/100600527/kisah-tentang-rotigambang-kenangan-menyantap-rotiterbaik-dunia?page $=$ all

Alamsyah, Y. (2008). Bangkitnya Bisnis Kuliner Tradisional. Jakarta: PT. Elex Media Komputindo.
Aljauhari, B. (2017, November 25). Perbedaan Etnis dan Suku Beserta Contohnya. Retrieved from Ilmugeografi.com: https://ilmugeografi.com/ilmusosial/perbedaan-etnis-dan-suku

Anugrah, K. (2018). Optimalisasi Usaha Kuliner di Obyek Wisata Hiu Paus Desa Botu Barani Kabupaten Bone Bolango, Gorontalo. Jurnal Pariwisata Pesona, 3(2), 191-204.

Astari, D. (2019). Perancangan Komik Makanan Khas Betawi. Yogyakarta: Institut Seni Indonesia Yogyakarta.

Balqis, S. (2015). Perancangan Mobile Application Pengenalan Masakan Khas Betawi Untuk Remaja Usia 22 30 Tahun Di Jakarta. Bandung: Universitas Telkom.

Begum , M. (2009). A Textbook of Foods,Nutrition And Dietetics. New Delhi: Sterling Publishers Pvt.Ltd.

Cho, J., \& Kim, S. (2018). Effects of Tourists' local food Consumption Value on Attitude, Food Destination Image, and Behavioral Intention. International Journal of Hospitality Management, 71, 1-10.

CNN Indonesia. (2019, October 18). Roti Gambang Betawi Jadi 50 Roti Terbaik di Dunia. Retrieved from CNN Indonesia: https://www.cnnindonesia.com/gayahidup/20191017180524-262-

440460/roti-gambang-betawi-jadi-50roti-terbaik-di-dunia

Edison, E., Kartika, T., \& Dewi, N. (2019). Persepsi Masyarakat terhadap Pengembangan Kawasan Wisata di Desa Kertawangi, Cisarua Kabupaten Bandung Barat . Journal of Indonesian Tourism, Hospitality and Recreation -, 2(2), 138-144.

Erwantoro, H. (2014). Etnis Betawi: Kajian Historis. Patanjala Jurnal Penelitian Sejarah dan Budaya, 6(2), 1-16.

Gálvez, J., López-Guzmán, T., Buiza, F., \& Medina-Viruel, M. (2017). Gastronomy as an element of 
attraction in a tourist destination: the case of Lima, Peru. Journal of Ethnic Foods, 4(4), 254-261.

Gardjito, M., Putri, R., \& Dewi, S. (2018). Profil Struktur Bumbu dan Bahan dalam Kuliner Indonesia. Yogyakarta: UGM PRESS.

Gultom, A. (2015). Faktor-Faktor yang Mempengaruhi Wisatawan Mengkonsumsi Makanan Tradisional di Restoran Kecamatan Simanindo Kabupaten Samosir. Jurnal Pendidikan Teknologi dan Kejuruan, 17(2), 50-53.

Harlandea, M. (2016). Sejarah dan Enkulturasi Musik Gambang Kromong di Perkampungan Budaya Betawi. Jurnal Seni Musik, 5(1), 2229.

Indonesia.go.id. (2018, Desember 27). Hikayat Nama Jakarta. Retrieved from Indonesia.go.id: https://www.indonesia.go.id/ragam/b udaya/kebudayaan/hikayat-namajakarta

Indriani , R., \& Frizona, V. (2018, Juni 22). Rayakan HUT Jakarta, 7 Camilan Betawi Ini Wajib Dicoba Milenial! Retrieved from Suara.com: https://www.suara.com/lifestyle/2018 /06/22/191500/rayakan-hut-jakarta-7camilan-betawi-ini-wajib-dicobamilenial

Irvansetiawan. (2019, November 25). Roti Gambang, Kuliner Legendaris dari Betawi. Retrieved from Kemdikbud: https://kebudayaan.kemdikbud.go.id/ bpnbjabar/roti-gambang-kulinerlegendaris-dari-betawi/

Jakarta tourism. (2018, February). Enjoy Jakarta. Retrieved from Jakarta Tourism.go.id: https://jakartatourism.go.id/visit/blog/2018/02/gam bang-bread

Jakarta Tourism. (2020). Sejarah Jakarta. Retrieved from Jakartatourism.go.id: https://jakartatourism.go.id/visit/blog/2013/12/sejar ah-jakarta
Jendela Informasi Kuliner . (2019, Oktober 20). Ini Asal Usul Nama Roti Gambang. Retrieved from Jendela Informasi Kuliner https://www.jendelakuliner.com/iniasal-usul-nama-roti-gambang/

Junaid, I. (2016). Analisis Data Kualitatif Dalam Penelitian Pariwisata. Jurnal Kepariwisataan, 10(01), 59 - 74.

Kementerian Pariwisata Indonesia. (2018). Laporan Akuntabilitas Kinerja Kementerian Pariwisata Tahun 2018. Jakarta: Kemenpar.

Ketaren, I. (2017). Gastronomi Upaboga Indonesia (Vol. 2). Jakarta: Indonesian Gastronomy Association.

Kompas.com. (2019, October 19). Roti Gambang Berasal dari Mana? Ini Asal Usulnya. Retrieved from Kompas.com:

https://travel.kompas.com/read/2019/ 10/19/093115327/roti-gambangberasal-dari-mana-ini-asalusulnya?page $=$ all

Krisnadi, A. (2018). Gastronomi Makanan Betawi sebagai Salah Satu Identitas Budaya Daerah. National Conference of Creative Industry Universitas Bunda Mulia (pp. 381-396). Jakarta: Universitas Bunda Mulia.

Kurniawan, F. (2010). Potensi Wisata Kuliner dalam Pengembangan Pariwisata di Yogyakarta. Surakarta: Universitas Sebelas Maret.

Lestari, N. S., \& Natalina, H. D. (2019). Kawa Daun, Kopi yang Bukan Berasal dari Biji Kopi. Jurnal Sains Terapan Pariwisata, 4(2), 262-276.

Lukmansyah, N., Wasino, \& Ahmad, T. (2016). Pengaruh Pembangunan di Jakarta Terhadap Sosial Ekonomi Masyarakat Betawi Tahun 19661977. Journal of Indonesian History, 5(1), 26-34.

Maligan, J. (2013, June). Indonesian Gastronomy (Food, Culture \& Local Wisdom). Malang: Universitas Brawijaya. 
Manoto, C. (2016, May 16). Roti Gambang. Retrieved from Perpusatakan Digital Budaya Indonesia: https://budayaindonesia.org/Roti-Gambang-2

Manzo, G., \& Smith, M. (2019). Destination 2030: Global Cities' Readiness For Tourism Growth. London: World Travel \& Tourism Council \& JLL.

Maurer, O. (2019). Tourism and Food: Necessity or Experience? In S. Beeton, \& A. Morrison, The Study of Food, Tourism, Hospitality and Events (pp. 27-35). Singapore: Springer.

Melfianora. (2019, September 12). Penulisan Karya Tulis Ilmiah dengan Studi Literatur. Retrieved from scribd: https://www.scribd.com/document/42 5488367/KTI

Mnguni, E., \& Giampiccoli, A. (2019). Proposing a Model on the Recognition of Indigenous Food in Tourism Attraction and Beyond. African Journal of Hospitality, Tourism and Leisure, 8(3), 1-13.

Muliani, L. (2019). Potensi Bubur Ase sebagai Daya Tarik Wisata Kuliner Jakarta. Destinesia Jurnal Hospitaliti \& Pariwisata, 1(1), 50-56.

Mutiah, D. (2019, Oktober 16). Gambang dari Betawi Masuk Daftar 50 Roti Terenak Dunia Versi CNN. Retrieved Oktober 22, 2019, from Liputan6.com:

https://www.liputan6.com/lifestyle/re ad/4087358/gambang-dari-betawimasuk-daftar-50-roti-terenak-duniaversi-cnn

Nariani, N. (2019). Pengembangan Kuliner Lokal Berdasarkan Persepsi Wisatawan Di Ubud, Bali. Journal of Tourismpreneurship, Culinary, Hospitality, Convention and Event Management, 1(2), 85-98.

Netralnews.com. (2017, June 22). Roti Gambang Khas Betawi dengan Rasa Manis yang Pas. Retrieved from Netralnews.com:

https://www.netralnews.com/gayahid up/read/83399/roti-gambang-khasbetawi-dengan-rasa-manis-yang-pas

Nugrahani , F. (2014). Metode Penelitian Kualitatif. Solo: Cakra Books.

Primadia, A. (2016, Oktober 25). Sejarah Jakarta Sebagai Ibukota. Retrieved from Sejarahlengkap.com: https://sejarahlengkap.com/indonesia/ sejarah-jakarta

Rara, A. (2019, Januari 19). Kue Khas Betawi yang Mencerminkan Karakter Warga Jakarta. Retrieved Oktober 24, 2019, from http://www.finroll.com/kue-khasbetawi-yang-mencerminkan-karakterwarga-jakarta/

Ridwiyanto, A. (2011). Batavia Sebagai Kota Dagang pada Abad XVII sampai Abad XVIII. Jakarta: Universitas Islam NEgeri Syarif Hidayatullah.

Sani, M., Alia, M., \& Riyadi, D. (2016). Sate Padang Sumatera Barat sebagai Gastronomi Unggulan di Indonesia. Gastronomy Tourism Journal, 3(1), 274-282.

Sari , F. (2015, September 24). Roti Gambang, Roti Legenda yang akan jadi Primadona Dunia. Retrieved from Sarihusada: https://www.sarihusada.co.id/NutrisiUntuk-Bangsa/Aktivitas/JelajahGizi/ROTI-GAMBANG-ROTILEGENDA-YANG-AKAN-JADIPRIMADONA-DUNIA

Sengel, T., Karagoz, A., Cetin, G., Dincer, F., Ertugral, S., \& Baliq, M. (2015). Tourists' Approach to Local Food. World Conference on Technology, Innovation and Entrepreneurship. 195, pp. 429 - 437. Istanbul: Elsevier Ltd.

Sert, A. (2019). The Effect of Local Food on Tourism: Gaziantep Case. Gaziantep University Journal of Social Sciences, 18(4), 1611-1625.

Setyorini, T. (2019, Oktober 18). Roti Gambang Disebut Salah Satu Roti Terenak di Dunia. Retrieved from 
Merdeka.com:

https://www.merdeka.com/gaya/rotigambang-disebut-salah-satu-rotiterenak-di-dunia.html

Sopia, S. (2020, Februari 22). Menu Khas Betawi di Kedai Starbucks, Bagaimana Rasanya? Retrieved from Republika.co.id:

https://gayahidup.republika.co.id/beri ta/q63hh7463/menu-khas-betawi-dikedai-starbucks-bagaimana-rasanya

Soraya, I. (2017). Personal Branding Laudya Cynthia Bella Melalui Instagram (Studi Deskriptif Kualitatif Pada Akun Instagram@Bandungmakuta). Jurnal Komunikasi, VIII(2).

Steinmetz, R. (2010). Food, Tourism and Destination Differentiation: The Case of Rotorua, New Zealand. Auckland University of Technology, School of Hospitality and Tourism. Aucland : Auckland University of Technology.

Suswandari. (2017). Local History of Jakarta and Multicultural Attitude (Historical Local Study of Betawi Ethnic). Journal of Education, Teaching and Learning, 2(1), 93-100 .

Sutisna, I. (n.d.). Betawi Cultural Village. Retrieved March 26, 2020, from Setu Babakan:

http://www.setubabakanbetawi.com/e $\mathrm{n} /$ profil-perkampungan-budayabetawi/

Tanico, Dafila. (2016). Melestarikan Minuman Tradisional Khas Jawa Timur sebagai Potensi Pengembangan Wisata Kuliner (CULINARY TOURISM) . Jurnal Pariwisata Pesona, 1(2), 1-6.

Tempat Wisata Indonesia. (2017, August 1). 54 Daftar Minuman dan Makanan Khas Betawi Jakarta. Retrieved from Tempat Wisata Indonesia: https://tempatwisataindonesia.id/mak anan-khas-betawi/

Tyas, A. P. (2017). Identifikasi Kuliner Lokal Indonesia dalam Pembelajaran Bahasa Inggris. Jurnal Pariwisata Terapan, 1(1), 1-14.
Untari, D., Avenzora, R., Darusman, D., Prihatno, J., \& Arief, H. (2016). Betawi Traditional Cuisines; Reflection the Native Culture of Jakarta (Formerly Known as Batavia). Journal of Economic Development, Environment and People, 6(4), 64-76.

Untari, D., Darusman, D., Prihatno, J., \& Arief, H. (2018). Strategi Pengembangan Kuliner Tradisional Betawi di DKI Jakarta. Ekuitas Jurnal Ekonomi dan Keuangan, 2(3), 313-340.

Utiket. (2020, Februari 07). Jakarta Sejarah. Retrieved from Utiket.com: https://utiket.com/id/obyekwisata/jakarta/sejarah-jakarta.html

Wolf, E. (2019). The Evolution of Food Tourism. Retrieved from World Food Travel Association: https://worldfoodtravel.org/what-isfood-tourism-definition-food-tourism/

World Tourism Organization. (2012). Global Report on Food Tourism. Madrid : World Tourism Organization.

Yustiana, E., \& Halim, M. (2019). Pusat Pagelaran Kesenian Betawi. Jurnal Stupa, 1(1), 445-455.

Zahrulianingdyah, A. (2018). Kuliner sebagai Pendukung Industri Pariwisata Berbasis Kearifan Lokal. Jurnal Teknologi Busana dan Boga, 6(1), 1-9.

Zainal, A., Zali, A., \& Kassim, M. (2010). Malaysian Gastronomy Routes as a Tourist Destination. Journal of Tourism, Hospitality \& Culinary Arts, 2(1), 15-24. 